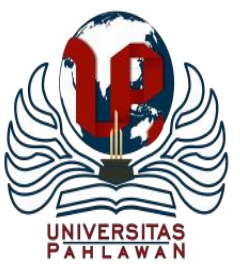

Jurnal Basicedu Volume 4 Nomor 3 Tahun 2020 Halm. 733 - 739

JURNAL BASICEDU

Research \& Learning in Elementary Education

https://jbasic.org/index.php/basicedu/index

\title{
Hubungan Motivasi Terhadap Tingkat Stress Mahasiswa Dalam Menulis Tugas Akhir (Skripsi)
}

\author{
Stefania Baptis Seto ${ }^{1}$, Maria Trisna Sero $\mathrm{Wondo}^{2}$, Maria Fatima $\mathrm{Mei}^{3}$ \\ Universitas Flores, Nusa Tenggara Timur, Indonesia ${ }^{1,2,3}$ \\ E-mail: stefaniseto6@gmail.com ${ }^{1}$, trisnawondo@gmail.com ${ }^{2}$, imajevan202019@gmail.com ${ }^{3}$
}

\begin{abstract}
Abstrak
Penelitian ini bertujuan untuk mengetahui hubungan antara motivasi belajar terhadap tingkat stres mahasiswa yang sedang menulis tugas akhir (skripsi). Jenis penelitian yang digunakan adalah penelitian kuantitatif. Populasi dalam penelitian ini adalah mahasiswa semester akhir Program Studi Pendidikan Matematika yang sedang menulis skripsi. Sampel dalam penelitian ini berjumlah 26 orang. Teknik pengambilan sampel menggunakan teknik simple random sampling. Hasil penelitian menunjukkan bahwa motivasi mahasiswa dalam menulis tugas akhir tergolong cukup yaitu sebesar $66 \%$ dan untuk tingkat stress mahasiswa berada pada kategori sedang yaitu sebesar 77\%, sedangkan hubungan motivasi terhadap tingkat stress mahasiswa diperoleh nilai Sig. (2-tailed) sebesar 0.000 dan diketahui nilai $r$ hitung sebesar 0.877. Berdasarkan hasil penelitian, dapat disimpulkan bahwa terdapat hubungan antara motivasi terhadap tingkat stress mahasiswa dalam penulisan tugas akhir (Skripsi).
\end{abstract}

Kata kunci: motivasi; tingkat stress; skripsi

\begin{abstract}
This study aims to determine the relationship between learning motivation and stress levels of students who are writing their final project (thesis). This type of research is quantitative research. The population in this research is the final semester students of Mathematics Education Study Program who are writing a thesis. The sample in this study amounted to 26 people. The sampling technique uses the Simple Random Sampling technique. The results showed that the motivation of students in writing their final assignments was quite sufficient at $66 \%$ and for the stress level students were in the moderate category at $77 \%$, while the relationship of motivation to student stress levels was obtained by Sig. (2-tailed) of 0,000 and the known $r$ count value of 0.877. Based on the results of the study, it can be concluded that there is a relationship between motivation and student stress levels in writing the final project (Thesis).
\end{abstract}

Keywords: motivation; stress level; thesis

Copyright (c) 2020 Stefania Baptis Seto, Maria Trisna Sero Wondo, Maria Fatima Mei

$\triangle$ Corresponding author :

Address : Ende, Nusa Tenggara Timur

ISSN 2580-3735 (Media Cetak)

Email : stefaniseto@gmail.com

ISSN 2580-1147 (Media Online)

Phone : 082236234895

DOI: $10.31004 /$ basicedu.v4i3.431 


\section{PENDAHULUAN}

Mahasiswa pada perguruan tinggi dituntun untuk segera mungkin menyelesaikan masa studinya. Pada umumnya di akhir masa studinya seorang mahasiswa diberi tugas akhir yang biasa disebut skripsi. Skripsi merupakan suatu karangan ilmiah yang wajib ditulis oleh seorang mahasiswa tingkat akhir sebagai persyaratan untuk menyelesaikan masa studinya. Skripsi juga menjadi salah satu bukti kemampuan akademik mahasiswa, selain sebagai persyaratan akhir pendidikan skripsi juga menjadi salah satu syarat untuk mendapatkan gelar sarjana. Proses penyusunan skripsi dilakukan secara individual oleh setiap mahasiswa. Dalam penyusunan skripsi dibutuhkan sumber yang banyak. Dengan membaca mereka dapat mengetahui sesuatu dan menambah pengetahuan tentang apa yang akan mereka kerjakan. Selain itu mereka juga harus memiliki semangat dan motivasi (Rahmi \& Marnola, 2020).

Hasil observasi peneliti pada salah satu mahasiswa, awalnya subyek memiliki semangat dan motivasi yang tinggi terhadap skripsi karena ia ingin cepat lulus kuliah, namun dalam perjalanannya menyusun skripsi semangat dan motivasi belajar sepertinya menurun seiring dengan hambatan atau kesulitan yang dialami dalam proses penyusunan skripsi.

Mahasiswa dihadapkan pada berbagai macam hambatan dalam proses menulis skripsi sehingga menyebabkan mahasiswa menjadi stress. Tingkat stres mahasiswa erat kaitannya dengan motivasi belajar yang dialaminya di kehidupan kampus. Stres merupakan suatu keadaan yang dialami oleh manusia ketika ada sebuah ketidak sesuaian antara tuntutan-tuntutan yang diterima dan kemampuan untuk mengatasinya (Looker \& Gregson, 2005). Penggolongan stres terdiri dari dua jenis yaitu stres yang membangun atau dikenal dengan istilah eustress. Eustress membuat seseorang menjadi bersemangat dan meningkatkan konsentrasi belajar, sedangkan stres yang sifatnya tidak menyenangkan dan bersifat negatif dikenal dengan istilah distress. Distress memberikan berbagai dampak negatif seperti menjadi gugup, tekanan darah tinggi, mudah marah, dan sulit berkonsentrasi. Stres akademik tergolong stres negatif (distress). Stres akademik terjadi didalam lingkungan pendidikan. Stres negsatif ini muncul ketika mahasiswa dihadapkan dengan tuntutantuntutan dan tugas yang harus dikerjakan oleh mahasiswa.

Penelitian yang dilakukan oleh (Mayoral, 2006) melakukan penelitian terhadap 334 responden yang sedang dan tidak skripsi. Hasil penelitiannya menunjukan bahwa mahasiswa yang sedang skripsi lebih banyak mengalami stres yaitu sebanyak $46,48 \%$. Penelitian juga dilakukan oleh (Pasaribu, 2018) hasil penelitian menunjukan tingkat stres mahasiswa dalam mengerjakan skripsi sebagian besar dalam berada dalam kategori stres sedang yaitu sebanyak 79 mahasiswa $(90,8 \%)$ dan motivasi mahasiswa mengerjakan skripsi tinggi sebanyak 82 mahasiswa $(94,2 \%)$. Hasil penelitian menunjukan bahwa semakin tinggi tingkat stres mahasiswa yang mengerjakan skripsi maka mtivasi mahasiswa yang mengerjakan skripsi semakin rendah yang dapat dilihat dari nilai hubungan kedua variabel negatif. 
Berdasarkan hasil penelitian yang dilakukan terdahulu maka dapat disimpulkan bahwa mahasiswa mengalami stres ketika ia mulai menulis tugas akhir skripsi. Sehingga sangat diperlukan motivasi dalam menulis skripsi. Pada dasarnya motivasi adalah suatu usaha yang disadari untuk menggerakkan, mengarahkan dan menjaga tingkah laku seseorang agar ia terdorong untuk bertindak melakukan sesuatu sehingga mencapai hasil atau tujuan tertentu. Motivasi dapat didefinisikan sebagai satu kekuatan dalam diri seseorang yang mendorong atau menggerakannya untuk memenuhi kebutuhan dan keinginan dasarnya. Motivasi bertujuan merangsang mahasiswa untuk bekerja dengan baik dan menggerakkan mahasiswa agar timbul keinginan dan kemauan untuk mencapai hasil yang diinginkan (Ernita S., Adnan F., 2019). Motivasi belajar adalah suatu dorongan yang timbul oleh adanya rangsangan dari dalam maupun luar sehingga seseorang berkeinginan untuk mengadakan perubahan tingkah laku atau aktivitas tertentu lebih baik dari keadaan sebelumnya (Hamzah B. Uno, 2017).

Selain itu juga motivasi adalah kekuatan yang mendorong mahasiswa atau seseorang untuk belajar, konsentrasi, perhatian dan mau mengerjakan tugas-tugas pembelajaran (Gagne, 1985). Motivasi merupakan variabel dimana dapat menimbulkan adanya faktor-faktor yang dapat mengelola, mempertahankan dan menyalurkan tingakh laku menuju suatu sasaran (Wulandari: 2012). Motivasi dibagi kedalam dua jenis yaitu motivasi intrinsik dan motivasi ekstrinsik. Motivasi intrinsik adalah yang datangnya dari dalam diri seseorang. Motivasi ini terkadang muncul tanpa pengaruh apapun dari luar. Sedangkan motivasi ekstrinsik adalah kebalikannya dari motivasi intrinsik, yaitu motivasi yang muncul karena pengaruh lingkungan dari luar.

Lazarus (Nursalim, 2013) mengatakan bahwa stres merupakan peristiwa-peristiwa fisik maupun psikologis yang dipersepsikan sebagai ancaman potensial terhadap gangguan fisik maupun psikologis. Ahli lain, Kartono dan Gulo (Safaria \& Saputra, 2009) menambahkan bahwa pengertian stres merupakan suatu kondisi ketegangan fisik dan psikologis yang disebabkan oleh adanya persepsi ketakutan dan ancaman. Helmi (dalam Safaria dan Saputra, 2009) menyatakan stres muncul ketika tekanan yang dihadapi melebihi batas optimum dari masingmasing individu. Selanjutnya pendekatan yang ketiga adalah pendekatan interaksionis yang menitik beratkan definisi stres dengan adanya transaksi antara tekanan dari luar dengan karakteristik individu yang menentukan apakah tekanan tersebut menimbulkan stres atau tidak. Menurut Handoyo (Fadillah, 2013) stress bisa berupa tuntutan dari eksternal yang dihadapi seseorang yang kenyataannya memang membahayakan atau menimbulkan permasalahan. Stres juga bisa dipahami sebagai tekanan, ketegangan atau gangguan yang bersumber dari eksternal dan dirasakan tidak menyenangkan.

Stres dibedakan menjadi dua jenis yaitu; stres yang merugikan dan merusak disebut distres dan stres yang positif yang menguntungkan disebut eustres. Selye (Safaria \& Saputra, 2009) 
mengatakan bahwa satu jenis stres yang sangat berbahaya dan merugikan disebut distres dan satu jenis lagi stres yang justru bermanfaat atau konstruktif disebut eustres. Menurut (Yusuf, 2006) menyebutkan faktor- faktor penyebab stres dapat berupa pengaruh internal seperti kondisi tubuh/fisik dan konflik pribadi, maupun pengaruh eksternal seperti keluarga yang kurang harmonis, orang tua yang otoriter, masalah ekonomi, dan lingkungan masyarakat. Jenis stres negatif atau yang disebut distres, dapat membawa kerugian bagi seseorang karena akan menimbulkan perasaan-perasaan tidak baik seperti cemas, ketakutan, dan kekhawatiran. Jenis stres negatif menimbulkan gejala-gejala yang akan nampak pada segi fisik, emosi, kognitif, dan interpersonal. Rice dalam (Septiani, 2013) mengatakan bahwa penyebab stres atau yang sering disebut stressor dapat berasal dari dalam diri individu (internal) dan dapat pula berasal dari luar diri individu (eksternal).

Mahasiswa tingkat akhir adalah mahasiswa yang sedang dalam proses menulis tugas akhir atau skripsi. Tugas akhir atau skripsi merupakan persyaratan untuk mendapatkan status sarjana (S1) di setiap Perguruan Tinggi Negeri (PTN) maupun Perguruan Tinggi Swasta (PTS) di Indonesia. Skripsi adalah syarat untuk memperoleh gelar kesarjanaan bagi mahasiswa (Yuliansyah, 2013). Menurut (Arikunto, 2015) skripsi adalah muara dari semua pengetahuan dan keterampilan yang pernah diperoleh sebelumnya untuk diterapkan dalam menggali permasalahan yang ada (baik dalam literatur maupun kancah) agar dengan penelitian itu dapat diperoleh temuan yang bermanfaat. Harahap, I. A \& Erniyati, (2014) menyatakan bahwa skripsi adalah laporan karya ilmiah dari hasil penelitian dan atau kajian mahasiswa yang dapat berupa bahasan dan rancangan oleh mahasiswa. Oleh karena itu motivasi sangat diperlukan mahasiswa dalam menulis skripsi.

\section{METODE}

Jenis penelitian yang digunakan adalah penelitian kuantitatif dengan uji Pearson Correlation. Populasi dalam penelitian ini adalah mahasiswa semester akhir Program Studi Pendidikan Matematika yang sedang menulis skripsi. Sampel dalam penelitian ini berjumlah 26 orang. Teknik pengambilan sampel menggunakan teknik simple random sampling. Variabel independen dalam penelitian ini yaitu motivasi belajar dan variabel dependennya tingkat stress dalam penyusunan skripsi.

Teknik pengumpulan data yang digunakan dalam penelitian ini dengan menggunakan instrumen angket yang akan mengukur motivasi mahasiswa dan angket untuk mengukur tingkat stress mahasiswa menggunakan skala Likert dan yang disebarkan menggunakan google form (dikarenakan situasi dan kondisi pandemi virus corona saat ini).

\section{HASIL DAN PEMBAHASAN}

1. Motivasi mahasiswa

Berdasarkan penelitian yang telah dilakukan motivasi mahasiswa tingkat akhir yang sedang menulis skripsi dapat dilihat pada gambar berikut. 


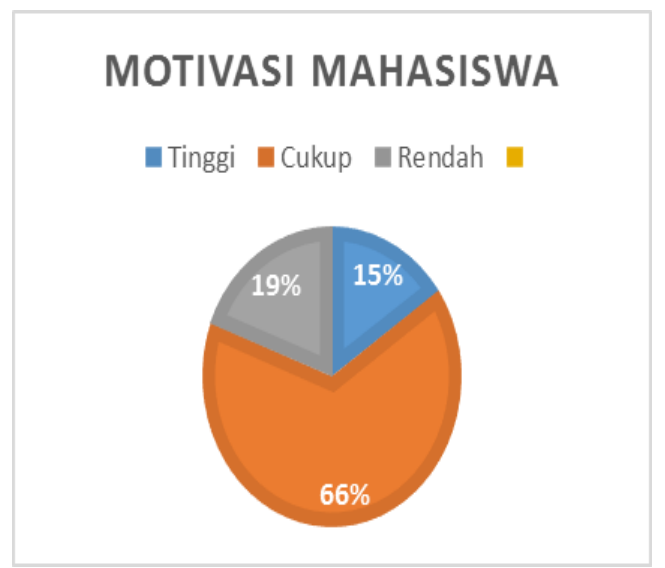

Gambar 1. Motivasi Mahasiswa

Berdasarkan gambar 1 diketahui bahwa motivasi mahasiswa dalam penulisan tugas akhir tergolong cukup sebesar $(66 \%)$.

2 Tingkat stres mahasiswa

Berdasarkan penelitian yang telah dilakukan tingkat stress mahasiswa tingkat akhir yang sedang menulis skripsi dapat dilihat pada gambar berikut.

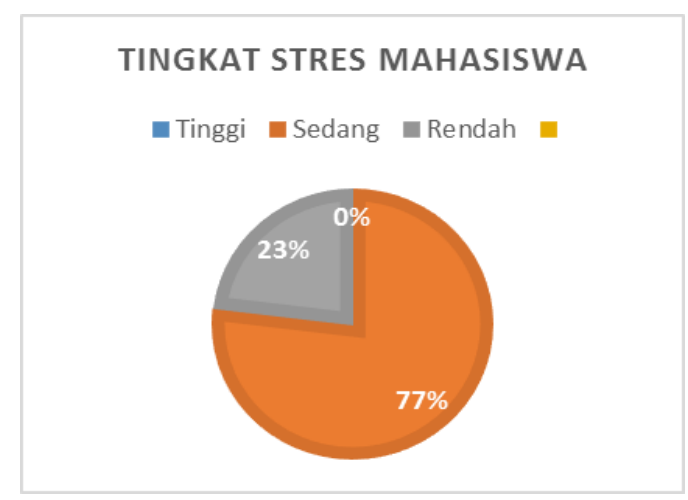

Gambar 2 Tingkat Stres Mahasiswa

Berdasarkan gambar 2 diketahui bahwa tingkat stres mahasiswa dalam penulisan tugas akhir tergolong cukup sebesar (77\%).
3 Analisis Hubungan Motvasi Mahasiswa terhadap Tingkat Stres

Pada penelitian ini dilakukan uji validitas dan reabilitas terhadap butir instrumen variabel motivasi sebanyak 16 butir soal. Berdasarkan hasil analisis korelasi product moment dengan menggunakan bantuan SPSS versi 0.20 maka diketahui dari 16 butir soal instrument angket terdapat 2 butir soal yang tidak valid dilihat dari hasil korelasi yang kemudian dibandingkan dengan nilai $\mathrm{R}$ tabel. $\mathrm{R}$ tabel dicari pada signifiklan 5\% dengan uji 2 sisi dan $n=26$, maka di dapat $r$ tabel sebesar 0.388 . berdasarkan hasil analisis didapat nilai korelasi untuk butir soal 4 dan 6 kurang dari 0.0.388. maka dapat disimpulkan bahwa itemitem tersebut tidak berkorelasi signifikan dengan skor total (dinyatakan tidak valid) dan harus dikeluarkan. Dari hasil analisis di dapat nilai Alpha sebesar 0.718 , sedangkan nilai $\mathrm{r}$ kritis (uji 2 sisi) pada signifikansi 5\% dengan $\mathrm{n}=26$ di dapat sebesar 0.388. maka dapat disimpulkan bahwa butir-butir instrumen penelitian tersebut reliabel.

Kemudian dilanjutkan dengan uji validitas dan reabilitas terhadap butir instrumen variabel tingkat stres sebanyak 20 butir soal. dari 20 butir soal instrument angket terdapat 4 butir soal yang tidak valid dilihat dari hasil korelasi yang kemudian dibandingkan dengan nilai $\mathrm{R}$ tabel. $\mathrm{R}$ tabel dicari pada signifiklan 5\% dengan uji 2 sisi dan $\mathrm{n}=26$, maka di dapat $\mathrm{r}$ tabel sebesar 0.388. berdasarkan hasil analisis didapat nilai korelasi untuk butir soal 2, 6, 18 dan 20 
Tabel 1. Analisis Korelasi Bivariate Person

\begin{tabular}{llll}
\hline & & $\begin{array}{l}\text { Motivasi } \\
\text { Mahasiswa }\end{array}$ & $\begin{array}{l}\text { Tingkat } \\
\text { Stress } \\
\text { mahasiswa }\end{array}$ \\
\hline Motivasi mahasiswa & Pearson Correlation & 1 & 0.877 \\
& Sig. (2-tailed) & & 0.000 \\
& N & 26 & 26 \\
Tingkat stress Mahasiswa & Pearson Correlation & 0.877 & 1 \\
& Sig. (2-tailed) & 0.000 & \\
& $\mathrm{~N}$ & 26 & 26
\end{tabular}

kurang dari 0.0.388. maka dapat disimpulkan bahwa item-item tersebut tidak berkorelasi signifikan dengan skor total (dinyatakan tidak valid) dan harus dikeluarkan. Dari hasil analisis di dapat nilai Alpha sebesar 0.887, sedangkan nilai $r$ kritis (uji 2 sisi) pada signifikansi $5 \%$ dengan $\mathrm{n}=26$ di dapat sebesar 0.388. maka dapat disimpulkan bahwa butir-butir instrument penelitian tersebut reliable.

Data yang diperoleh selanjutnya akan dilakukan analisis uji pearson correlation bivariate dengan menggunakan spss.

Berdasarkan tabel di atas, hubungan antara motivasi dengan tingkat stres mahasiswa memiliki nilai Sig. (2-tailed) sebesar $0.000<0.05$, yang berarti terdapat korelasi yang signifikan antara variabel motivasi dengan tingkat stress. Nilai $r$ hitung (pearson correlations) untuk hubungan motivasi mahasiswa dengan tingkat stress mahasiswa adalah sebesar $0.877>0.388$, maka dapat disimpulkan bahwa ada hubungan atau korelasi antara motivasi dengan tingkat stres.

Berdasarkan analisis data di atas dapat disimpulkan bahwa terdapat korelasi atau hubungan antara motivasi mahasiswa terhadap tingkat stress mahasiswa dalam penulisan tugas akhir (skripsi).

\section{SIMPULAN}

Berdasarkan hasil penelitian diperoleh motivasi mahasiswa tergolong cukup (66\%) dan untuk tingkat stress mahasiswa berada pada kategori sedang yaitu sebesar (77\%) dan untuk hubungan motivasi terhadap tingkat stress mahasiswa diperolehnilai Sig. (2-tailed) sebesar $0.000<0.05$ dan diketahui nilai $r$ hitung sebesar 0.877>0.388, maka dapat disimpulkan bahwa terdapat hubungan yang bermakna antara motivasi terhadap tingkat stress mahasiswa dalam penulisan tugas akhir (skripsi).

\section{DAFTAR PUSTAKA}

Arikunto. (2015). Prosedur Penelitian Suatu Pendekatan Praktik. Rineka Cipta.

Ernita S., Adnan F., H. (2019). Pengaruh Model Scientific Inquiry Terhadap Motivasi dan Hasil Belajar Tematik Siswa Kelas IV SD. Jurnal Basicedu, 3(2), 385-390.

Fadillah, A. E. R. (2013). stres dan motivasi belajar pada mahasiswa psikologi Universitas Mulawarman yang sedang menyusun skripsi. Universitas Mulawarman.

Gagne, R. M. (1985). he Condition of Learning Theory of Instrucion. Rinehart. 
Hamzah B. Uno. (2017). Teori Motivasi dan Pengukurannya. Bumi Aksara.

Harahap, I. A., \& E. (2014). Panduan Penulisan Proposal dan Skripsi Edisi 2. Universitas Sumatera Utara.

Looker, G. (2005). Managing Stress: Mengatasi Stress Secara Mandiri.

Mayoral, L. (2006). Exam stress, depression, social support, and sleep disturbance. San Jose State University.

Nursalim, M. (2013). strategi intervensi dan konseling. Indeks.

Pasaribu, B. . (2018). Hubungan Tingkat Stres dengan Motivasi Mahasiswa Mengerakan Skripsi di Fakultas Kesehatan Masyarakat USU. Universitas Sumatera Utara.

Rahmi, Y., \& Marnola, I. (2020). Peningkatan Kemampuan Membaca Pemahaman Siswa Melalui Metode Pembelajaran Cooperative Integrated Reading And Compotion (CIRC). Jurnal Basicedu, 4(3), 662-672. https://doi.org/10.31004/basicedu.v4i3.406

Safaria, S. (2009). Manajemen Emosi. Bumi Aksara.

Septiani, E. (2013). Hubungan antara tingkat stres dengan gaya humor pada mahasiswa(Skripsi). UIN SGD.

Yuliansyah, M. W. (2013). Pengaruh Terapi Jurnal Terhadap Penurunan Tingkat Kecemasan Mengerjakan Skripsi Pada Mahasiswa Psikologi UNS. Universitas Sebelas Maret Surakarta.

Yusuf, S. (2006). Mental Hydiene: Pengembangan Kesehatan Mental dalam Kajian Psikologi dan Agama. Pustaka Bani Qurasy. 